\title{
REPOSITION OF WIDOW BY DEATH DIVORCE IN BATAKNESSE INHERITANCE LAW FROM GENDER PERSPECTIVE
}

\author{
Amri P. Sihotang \\ Doctoral Program of Law Sultan Agung Islamic University Semarang \\ amripanahatan20@gmail.com
}

\begin{abstract}
This journal is to study the reposition of widow in traditional Batak's hereditary law by using gender approach. The Batak's hereditary Law, tends to be referring to patrilineal kinship which is determined from the line of father's or husband's descent so the Widow is not the beneficiary of the husband but the son in the Batak's ethnic and culture. Along with the current development and important role of a mother/woman in family life, it is important to re-study more deeply the position of a widow in Batak's hereditary law and some related theories which one of themis gender approach.This is considerably important because there are some modern thinker related to customary law who intend to renew the law especially the beneficiary for the sake of gender equality in the current ages by bilaterally repositioning widow to the national hereditary law . By Educating Batak's hereditary law from gender perspective, the Batak's ethic will be able to critically think and flexibly find solution to share the property by positioning the widow as the beneficiary or the heir.
\end{abstract}

Keywords : reposition, position of widow, inheritance law

\section{Introduction}

Every nation or ethnic has its spesific culture, therefore each community has its own law which differs from one to another. This difference shows that every community has its characteristic as the identity of the nation related to locale wisdom. In this case, customary law is a set of regulatory or rule of humanbeings who live in a community ${ }^{1}$.

Hereditary Law in Indonesia differs from one region to another, some adopt Burgerlijk Wetboek (BW) Hereditary Law (civil law) dan Islamic hereditary law. Custom hereditary law in this case shows the characteristic of Indonesia culture. Therefore, custom hereditary law shows the basic difference compared to civil and islamic hereditary law.

When we are discussing the custom hereditary law, we also talk kinship system . by this system, we can find out who entitles to receive benefits including the widow. Theoritically, the kinship system is distinguished in three characters, which is :

1. Patrilineal system, a kinship from the line of the father where Men have special inheritance position than women.

\footnotetext{
${ }^{1}$ Hilman Hadikusuma. Introduction to Indonesian Traditional Law Science. (Bandung: Mandar Maju, 2003$), 1$.
} 
2. Matrilineal system, a kinship from the line of the mother where women have special inheritance position than men.

3. Parental or Bilateral system, a kinship from two lines (the father and mother) where men and women have equal inheritance position, no differentiation ${ }^{2}$.

Batak's ethnic is one amongst customary law in Indonesia. They are purely applying patrilinel line, meaning each individual in the ethnic is following their father's line where the sons have special influence than the daughters ${ }^{3}$ In addition, a widow is not the beneficiary of her death husband in Batak's law. J.C Vergouwen added :The right to replace from the line of a man will be instantly happened by the birth of a son(s), He is the executor related the continuity of the father's line ${ }^{4}$

The gender bias is clearly seen in Batak's community. Gender influence and women emansipation, there is a demand from the modern thinker re batak's customary law to renew the law in accordance with the new era especially beneficiary/heirs right by placing the widow as a heirs.

According to Act No.1 year 1974 about Marriage, article 38 states : marriage can be splitted by (a) Divorce, (b) Death, (c) Decision of the court. Batak's community which is purely patrilineal, if marriage splited by divorce, then a meeting must be conducted beforehand, a so called Hasirangan, where the purpose of this meeting is to determine who is guilty therefore community property will be discussed. However, when marriage splitted by death then the problem occurs related to benficiary and custody of the children.

From the feminist point of view, Batak's hereditary law is generally patriarkat and not sensitive to the position of the woman as well as their interest so they are demanding the law to be renewed. This patriarchal culture is the perspective stating that men dominate all role in the social system; as women are neglected from the role they can also do like men. ${ }^{5}$

However, there is a resistancy especially from the group of people who claim themselves as the authority of the customary law. The reason is, changing the custmary law is consideably jeopardying which means it will change the essence of Batak's culture.On the other hand, maintaining the customary law, though it is irelevant to the community's need, is to keep up the

\footnotetext{
${ }^{2}$ I. Gede Ab Wiranata. Customary Law in Indonesia. (Bandung: PT. Citra Aditya Bakti, 2005), 15-17.

${ }^{3}$ Zainuddin Ali. Implementation of the Law of Inheritance in Indonesia. (Jakarta: Sinar Grafika, 2008), 25.

${ }^{4}$ C. Vergouwen. Society and Customary Law of Toba Batak. (Yogyakarta: PT. LkiS Pelangi Aksara, 2004)

5 Ani Purwanti, "Protection and Rehabilitation for Women Victims of Violence according to Indonesian Law (Study on Central Java Government's handling through KPK2BGA)," Diponegoro Law Review 02, No 02 (October 2017): 313.
} 
power of customary law. As a result, not many Batak's people renewing the law especially related to hereditary law.

Act No.1 Year 1974 about Marriage article 31 states :

(1) The rights and position of a wife are equal with the husband in their marriage life as well as in the community

(2) Each party is eligible to conduct legal action

(3) A husband is the head of the household and wife is the housewife

From this point, some backgrounds can be described from the above explanation, therefore the importance of this study is to explore more what is the real position of a widow in Batak; $\mathrm{s}$ hereditary law and how to reposition a widow from gender perspective along with the current development and progressive era.

\subsection{Formulation of problem}

Refering the background explained above, the principal problem has been formulated as below :

1. What is the real position of a widow in Batak's hereditary law?

2. How to reposition a widow in Batak's hereditary law from gender perspective?

\subsection{Framework Theory}

Some Law's theories can be used as a base or guideline to codify herditary law as such :

1. Roscou Pound, Law as a tool of social engineering. Roscoe Pound then explained that law as a social institution can be enhanced by human efforts through scholars and considered as obligation to find the right way to imporve ${ }^{6}$

2. 2. Lawrance M. Friedman Theory. This theory can be used as tool analysis as an effort to form national hereditary law using bilateral system. Friedman further evplained that Law structure has three elements, which is Law's structure : substance or law material : and culture of the law. The use of Friedman theory is to support Rosco Pound theory, mainly the emphasis towards the function of hereditary law as a social control. According to Friedman, The system of law which becomes social control makes other sytem to be secondary or underneath the system of law ${ }^{7}$

\footnotetext{
${ }^{6}$ Abdurrahman. Compilation of Islamic Law, Print I. (Jakarta: Akademika Presindo, 1992), 19.

${ }^{7}$ Lawrence Meir Friedman. American Law: an Introduction, Second Edition, Terj. Wishnu Basuki with title, American Law: An Introduction, Prints I. (Jakarta: PT Tatanusa, 2001),7-8.
} 
3. Carl Von Savigny Theory. "Das Recht wird nicht gemacht, est und wird mit dem volke ${ }^{\prime \prime}$ According to Savigny : Law is note made, but grows and develops along with the community as living law. For that reason, good law is a law which can live up and grow in the community and becomes guideline for the community to behave.

Savigny theory was introduced in Indonesia by Soepomo by placing customary law as a standard. Furthermore as Soepomo said, customary law is a lively law because it represents a real law's feeling in the real community which is dynamic and up to date along with the development of the community. Hereditary law is a customary law which contains of guidelines toards the systemand foundations of hereditary laws, about the inheritance, beneficiary and the method to divert the inheritance. ${ }^{9}$

\subsection{Laws governing the Discrimination of Women}

A. Convention on the Elimination of All Forms of Discrimination against Women, dated December 18, 1979, ratified by Indonesia with the issuance of Law no. 7 of 1984 on the Ratification of the Convention on the Elimination of All Forms of Discrimination Against Women. Article 2 states "The State Party to this Convention condemn discrimination against women in all its forms and agree to pursue by all appropriate means and without delay, a policy of eliminating discrimination against women, and to that end, undertake: (a) to include the principle of equality between men And women in their National Constitution or other appropriate legislation, if not already included in it and to ensure the practical realization of this principle, by law and other appropriate means; (B) make appropriate legislation and other regulations including sanctions where necessary, prohibit all discrimination against women; (C) make appropriate rules for the elimination of discrimination against women by any person, organization or enterprise; (D) make appropriate regulations, including the making of laws, regulations, practices, and discriminatory practices against women ".

B. Law no. 39 Year 1999 on Human Rights, Article 51 paragraph (1) "a wife for the marital bonds have rights and responsibilities with her husband for all that pleased with his marriage, a relationship with his children, and the rights of ownership and management Joint treasure "; Paragraph (2) "after the breakup of marriage, a woman has the right and responsibility together with her ex-husband for all the things that are pleasing with their children, the best

\footnotetext{
${ }^{8}$ Lili Rasyidi, at all. Fundamentals of Philosophy and The Theory of Law, Prints IX. (Bandung: PT Citra Aditya Bakti, 2004), 65

${ }^{9}$ Soepomo. The Legal System in Indonesia Before World War II, Print XV (Jakarta: PT Pradnya Paramita, 1997$)$, 7.
} 
interests of the child"; Paragraph (3) "after the breakup of marriage, a woman has the right and responsibility of the same with her ex-husband for all the things that are pleasing to the joint property without prejudice to the rights of children, in accordance with the provisions of the legislation".

With the ratification of the Convention on the Elimination of All Forms of Discrimination Against Women and the Law of Human Rights is supposed to elders and elders Batak rethink and examine the principle and the principle of discriminatory, so that equality between women and men put forward either in the family, customs, and in All the social life of Batak society.

\section{Method}

\subsection{Method of Approach}

Approach method used in this research is normative juridical method, that is law research done by researching or studying problem seen from facet of rule of law, researching library material or secondary data. ${ }^{10}$ The author uses the method of normative in this study with a view to an inventory of legal materials (collecting, classifying and clarifying) in order to examine the consistency and synchronization of the position of widows in the customary law of inheritance Batak.

\subsection{Research Specification}

In terms of its objectives, this research is descriptive analytical, which describes the prevailing laws and regulations relating to legal theories and practice of the implementation of positive law, concerning the above problems ${ }^{11}$ Descriptive in this research is intended to provide a detailed, systematic and comprehensive description of all matters relating to the position of divorced widow in the customary law of Batak and repositioning the status of widow in the customary law of Batak in the perspective of gender, while analytical means grouping, Linking, explaining and giving meaning to the subject matter to be analyzed so as to give a clear picture of the problem.

\subsection{Data Sources}

The type of data used in this study is secondary data, considering this research using normative legal approach, the main data source is secondary data. Secondary data in the field of law (viewed from the angle of binding strength) can be divided into:

\footnotetext{
${ }^{10}$ Soejono, at all. Legal Research Methods. (Jakarta: Rineka Cipta, 2003), 56.

${ }^{11}$ Moch Nazir. Research methods. (Jakarta: Ghalia Indonesia, 2008), 84.
} 
a. Primary legal materials, namely legal materials comprising legislation, official minutes, court decisions and official state documents.

b. Secondary law materials, namely legal materials consisting of books or legal journals containing the basic principles (legal principles), the results of legal research, legal dictionary and encyclopedia law.

\subsection{Data Collection Method}

In this study, the above secondary data were obtained by library research (library research). Library study is a research done by searching for conceptions, theories, opinions or legal findings ${ }^{12}$ which is closely related to the subject matter.

\subsection{Data Analysis Method}

Data analysis method is an important step in determining a research. Data analysis in a study is to describe or solve the problems studied based on the data obtained and then processed into the subject matter of the proposed descriptive research ${ }^{13}$

Data analysis method used in this research is descriptive qualitative analysis method, that is how to analyze data by describing and analyzing content material and validity of data obtained from result of library study, so that got picture about an event in society, in this case is about position of widow in the customary law of Batak's inheritance and repositioning the position of widow in the customary law of Batak in the perspective of gender

\section{Result and Discussion}

\subsection{Position Of Widow In Traditional Batak Hereditary Law}

\section{a. Position of Widow according to Customary Law}

The position of the widow as an heir or not, is influenced by the kinship system and marriage form applicable within the society concerned. There is a widow who, due to the death of her husband, is still not free to determine her conduct, because she still has to be domiciled on the side of her husband's relative, but there is also a widow who after her husband's death can return to her original relative and freely determine her behavior ${ }^{14}$

\footnotetext{
${ }^{12}$ Suharsimi Arikunto. Research Procedures A Practice Approach. (Jakarta: Rineka Cipta, 2008), 109.

${ }^{13}$ Heribertus Sutopo. Introduction to Qualitative Research. (Surakarta: Puslitbang UNS, 2008), 8.

${ }^{14}$ Hilman Hadikusuma. Customary Law of Inheritance, Cet, 7. (Bandung: PT. Citra Aditya Bakti, 2003), $212-213$.
} 
The widow's position in the customary law of the heritage property, starting from the principle that women as foreigners have no right to inherit ${ }^{15}$ This happens when the terms of inheritance are a familial strap based on the equation of blood or offspring. Therefore, in the formulation of the inheritance of the rights of widows must be considered, among others:

1). Widow is entitled to life guarantee of her life, from result of gono-gini or from result of goods of origin of husband.

2). The widow is entitled to take possession of her husband's estate, to withdraw the income of the goods, especially if having children, the treasure is still unity under the care of the widow and not divided.

3). The widow is entitled to retain her husband's goods, as long as the goods are required by her, for her necessities.

4). The widow is entitled to share or demand for the child's share, in the event of a division with the child, for example the pregnant widow or the child requesting partly for business capital.

It is worth noting that there must be two conditions, in order for the widow to obtain a position as an heir:

1). Widows must have long lived together and follow the joy of family

2). Widow, after the death of the husband does not show attitude or tend to break the relationship with the husband's family, nor married again to another man ${ }^{16}$

In Indonesia, there are 3 (three) forms of kinship system, which in some way influence the position of widow.

1). Widows in Patrilineal System

Patrilineal society in Batak, tied to patrilineal system that is absolutely genealogical, that is draw a lineage from the father. The main feature of this patrilineal society is marriage with Honest. Honestly, this giving by the male to the woman is as a symbol of the family's decision to decide the family relationship with his relatives and entered into her husband's relative.

2). Widows in Matrilineal System

The matrilineal lineage system is the one that calculates the kinship relationship through women only, and it results in each individual entering into his mother's relative

3). Widows in Parental System

\footnotetext{
${ }^{15}$ Iman Sudiyat. Legal Waris Indonesia. (Bandung: Refika Aditama, 2005).

${ }^{16}$ Muhammad Busar. Principles of Customary Law, Cet.3. (Jakarta: Pradnya Paramita, 1985), 28.
} 
Javanese society is a society that has a parental / bilateral kinship system, that is, each individual draws his or her lineage upwards through the father and mother line simultaneously or simultaneously. According to Javanese customary law, heirs can be classified in the following order:
A). Descendants of the testator.
B). Parent heir.
C). Hereditary brothers / descendants.
D). Parents of the parents of inheritors.

\section{b. Position of Widow in the Law of Traditional Batak Inheritance (Batak's Hereditary}

\section{Law)}

\section{1). Position in related with Kinship System and Marriage Form}

In the patrilineal community in Batak every person who is born always draws a lineage through men / father. The born boy always draws a lineage through his father, so that the born children have a legal relationship with father and father's family. As a result of this hereditary principle, the boys' position becomes important, because boys are the descendants of the offspring. Can be said boy forever seklan with father and his father's family. Therefore, in the Batak community with patrilineal system, the residence is the father's part.

So is the case with the wife, where his residence depends on the husband (patri-local). It happens as a result of the marriage form that applies to this society, namely "honest marriage". In this marriage there is an honest goods given by the men to the women, which serves to replace the magical emptiness that occurs within the family of female origin. This honest item is important in maintaining the magical balance that exists within the family of female origin. With the existence of such an honest marriage, the consequence that the wife escaped the rights and responsibilities of the family of origin and entered into the rights and duties and responsibilities of her husband's family.

If the marriage breaks up, then it depends on the cause of the breakup of the marriage. If the marriage breakup is due to a divorce, then a meeting, the "attendance meeting", will be held to determine who is wrong and will talk about sharing the common property. If it turns out that the meeting decides that the husband is guilty, then the wife will get a larger share of the joint property, and vice versa if it turns out the wife is guilty, then the husband will get a greater share than his wife. 
If the marriage breakup is caused by death, then there arise the issue of inheritance and maintenance of the child. If the deceased is a husband, then it is appropriate if the mother (widow) who continue the maintenance of the child who is under age and control of the child's wealth obtained as a legacy from his father who has died.

In this case, the widow is only granted the right to control and enjoy the property (not owning), and later on, the property will belong to her son or to the family of her late husband if she remarries or has no offspring. So it is clear that according to the customary law of the Batak community, it does not give the widow an opportunity to inherit the heritage of her husband. This is reinforced by the opinion of Sulistyowati Irianto who said:

1. Cultural values and concepts concerning women and men in the Batak community reflecting the unequal power relations between men and women, placing women in a weak position especially in terms of inheritance.

2. The absence of territorial factors in the city does not result in reduced validity of cultural values that impact on the weakness of women's position in inheritance.

3. The migration of Batak people to the city precisely reinforces the existence of customary rules of inheritance in certain respects. Values about heritage possessions that girls may not have in their homeland, adopted in such a way that the property of marriage (matrimonial property) was considered not entitled to be owned by girls in certain Batak communities in the city.

4. With regard to the widow, the customary inheritance that does not place the widow as an heir, is still preserved in the city, in which the widow along with her husband has collected the treasures during her married life.

5. The impact of patriarchal control on women in cities has led to an increasingly sharp social and economic stratification by gender ${ }^{17}$

\section{2). Widow's Position in Relation to the Principles of Inheritance and the Inheritance}

\section{System}

In customary law of inheritance (hereditary law), to determine the heirs are based on the principle of inheritance, where the prevailing principles are different from one society to another. The principle consists of, general principles and special principles. The principle of general inheritance is the principle whereby to be an heir must have a blood relation with the heir, in

${ }^{17}$ Sulistyowati Irianto. Approach to Women's Wise Law, in the Elimination of Discrimination Against Women. (Bandung: Alumni, 2000), 9. 
other words that the heir must be the heir of the heir. The special principle is to become an heir not only to have blood relation, but also to one clan with heir.

In the Batak society which is a community berklan, adheres to both principles. Where to perform inheritance, a person must have a blood relation with heir and must be a clan with heir. So in this society, the inheritance is a boy. This is because boys are the descendants of descent or defending the father's clan and father's family.

In relation to that, if the deceased is a husband, it is clear that the widow can not appear as an heir to inherit the estate of her deceased husband, because the widow has no blood relation and not one clan with her deceased husband but a clan with her family of origin . But by doing an honest marriage, he has gone out of his family clan. So it can be said that the widow is not the heir of her late husband.

In addition to the principle of inheritance, it must be considered also about the inheritance system. In customary law there are three systems of inheritance, namely:

a). Individual inheritance system, a customary legal system of inheritance in which, inheritance is distributed to relatives and may be owned individually with property rights. This inheritance system is applicable among parental society, western law (KUH Perdata), as well as in Islamic inheritance law.

b). The collective inheritance system, a customary legal system of inheritance which does not allow heirs to have personal possessions: they are only allowed to use, labor, or process and enjoy the results.

c). The major inheritance system, a customary legal system of inheritance in which the property is not divided and is controlled only by the eldest child.

The Batak community embraces the individual inheritance system, where in this system the treasure of the relics will be divided to the heirs according to their respective sections. But of course only boys are entitled to get a share of the treasure. If it turns out that the family does not have sons, then the inheritance falls to the brother of the heir, which in Batak is known as "manean" or "tean-sejanan", this brother is called "panean" Or "manean". If the brother of the heir does not exist, the inheritance falls to the family near the heir, drawn along the line of the father.

Thus, it is clear that if the widow's position is associated with the inheritance system and the inheritance principle, then it can be said that the widow can not inherit her husband's estate, because the widow is not the heir of her deceased husband. 


\section{3). Position of Widow of Husband's Heritage in the Principle of Justice}

A widow in a patrilineal society in Batak, after the death of her husband, has the right to enjoy all the livelihoods and other property brought by the husband and wife into the marriage, as long as the widow does not remarry and remains in the family of her deceased husband. But usually, a widow if she has a married son, then the child's duty to buy and keep the widow.

If there is a division of inheritance and her son is not likely to buy or keep the widow, then some of her husband's estate must be abandoned and handed over to the widow for the provision of his life. If the widow dies, then the property is subdivided by the heirs or if previously, has been determined to be controlled by the widow, then the heirs can only control that part, if the widow has died, the heirs have no right to disturb the widow's rights.

The right to enjoy is limited only to the things that are necessary and appropriate for the widow's life. But to sell goods belonging to her deceased husband, must get approval from close family / other heirs. According to Batak custom law, widow is not heir to her husband's estate, but widow only serves as:

a). Superintendent or keeper of the estate, replacing the position of the deceased husband in order to safeguard the interests of the heirs.

b). As long as the widow is alive, it is entitled to master and enjoy the treasures and sert

c). The nature of such supervision and enjoyment shall not reduce or separate or sell the property. The sale can only be done if it has been approved by other heirs. However, keep in mind, that the supervision and enjoyment will disappear by itself, if the widow has been out of the family of her late husband or the widow do marriage with man Other than the relatives of her late husband.

\section{4). Sections of Widows in Traditional Batak Inheritance in the Principle of Justice}

The widow in the Batak area in the form of marriage to use honestly after the death of her husband remained domiciled in the place of her husband's relatives, she still deserve to enjoy the wealth left by her husband, even though he is not inherited from her husband. In the Batak land, widows are not inherited from their husbands, but they have been entitled to life for their husbands in the limits of their livelihood. It can be seen from the following court decisions:

According to the South Tapanuli District Court Decision dated December 12, 1953 No.81 / 1953 / SHP.Ps, it is said that according to customary law in the Batak area a widow woman can not inherit the land of her husband. Then the High Court of Medan Decision dated April 23, 1957 No.50 / 1954 said, according to the customary law of Batak a widow of women can not 
inherit the land of her husband, but can demand to keep enjoying the land of her husband, as long as the treasure is required for His livelihood.

If the widow in the patrilineal system is not the heir of the husband, but is the bridge or inheritance bridge of the father to his sons, then so is the husband actually not the heir of his wife who died, because according to the mind nature in this kinship system wife belongs Husband, let alone possessions and livelihoods that during the marriage is a unity that is not separated and not fragmented.

From the estate of her husband, the wife does not get a share as an inheritance, but the right to withdraw income from the treasure for life, if necessary. For that living, the wife (widow) can also be given a decent share of her husband's estate, which is often the case when her children are all grown and mentas and mencar (not home anymore). The widow has the right to earn a living so that, for that purpose, sometimes the treasures left to her are not divided, as well as the goods of her husband's origin.

\subsection{Reposition Of Widow's Status In The Law Of Traditional Batak's Inheritance In Gender Perspective}

\section{a. Understanding Gender}

Gender issues are not a new issue in social, legal, religious, or other studies. Nevertheless, gender studies are still actual and interesting, as there are still many societies, especially those in Indonesia who have not understood this issue and there are still many disparities in the application of gender so as to lead to gender inequality.

Gender is often identified with gender, whereas gender is different from gender. Gender is often also understood as a gift from God or the divine nature, whereas gender is not solely that. Etymologically the word 'gender' comes from English meaning 'gender' ${ }^{18}$ The word 'gender' can be defined as' the apparent differences between men and women in terms of values and behavior $^{19}$

In terminologically, 'gender' can be defined as cultural expectations of men and women ${ }^{20}$ Another definition of gender is put forward by Elaine Showalter. According to him, 'gender' is a differentiation between men and women from socio-cultural constructs ${ }^{21}$ Gender can also serve

\footnotetext{
${ }^{18}$ John M. Echols, at all. English-Indonesian dictionary. (Jakarta: Gramedia. Cet. XII, 1983), 265.

${ }^{19}$ Victoria Neufeldt (ed.). Webster's New World Dictionary. (New York: Webster's New World Clevenland, 1984), 561.

${ }^{20}$ Hilary M Lips. Sex and Gender: An Introduction. (London: Myfield Publishing Company, 1993), 4.

${ }^{21}$ Elaine Showalter (ed.). Speaking of Gender. (New York \& London: Routledge, 1989), 3.
} 
as a concept of analysis that can be used to explain something ${ }^{22}$ More emphatically mentioned in the Women's Studies Encyclopedia that gender is a cultural concept used to distinguish the role, behavior, mentality, and emotional characteristics between men and women who develop in society ${ }^{23}$ The history of gender differences between a man and a woman takes place through a very long process and is formed by several causes, such as socio-cultural conditions, religious conditions, and state conditions. With this long process, the final gender difference is often regarded as God's natural or as if biologically irreversible provision. This is precisely what caused the beginning of gender inequality in the midst of society.

Gender has an important position in the life of a person and can determine the life experience that will be taken. Gender can determine one's access to education, the world of work, and other public sectors. Gender can also determine the health, life expectancy, and freedom of movement of a person. Clearly, gender will determine the sexuality, relationships, and ability of a person to make decisions and act autonomously. Finally, it is the gender that determines what a person will become.

\section{b. Position of Widow in Traditional Batak Inheritance Law in Gender Perspective}

A number of studies on women and law in Indonesia concluded how marginal the position of women. This women's inferiority has been generally imprinted to the society which is supported with several legitimacy, starting from philosophy, religious doctrine, until the positive law itself ${ }^{24}$ Gender inequality in male and female relation in Indonesia is still very strong. As seen in the system of inheritance of the adat Batak custom which adheres to the patrilineal system, where women do not get inherited property and are economically dependent on men.

Gender issues have been frequently discussed and discussed by gender observers in various meetings, discussions, seminars and others at the local level, as well as at the national level even at the international level. Mansour Fakih, suggests that gender is a socially male and female relationship. The social relationships between men and women in the daily life of society, formed and transformed by society itself, therefore, are dynamic, meaning they can change from time to time, and can also differ from one place to another in line with Culture of their respective communities $^{25}$

\footnotetext{
${ }^{22}$ Nasaruddin Umar. Gender Equality Argument: The Perspective of the Qur'an: Cet I. (Jakarta: Paramadina, 1999), 8.

${ }^{23}$ Siti Musdah. Islam Sues Polygamy: Cet I. (Jakarta: Gramedia Pustaka Utama, 2004), 4.

${ }^{24}$ Suteki, at all. "The Strategies Of Women Protection In Solving Domestic Violence Cases In Central Java Through Sheltered House," Diponegoro Law Review 01, No. 01 (October 2016): 115.

${ }^{25}$ Mansour Fakih. Gender Analysis \& Social Transformation. (Yogyakarta: Pustaka Pelajar, 1996), 8.
} 
The social relationships between men and women can be seen in various areas of life, among others, in the political, social, economic, cultural and legal fields (both written and unwritten law ie customary law). The social relationships between men and women in these various areas of life generally show sub-ordination relationships which means that the position of women is lower when compared to the position of men.

The subordinated relationships are experienced by women all over the world because the subordinated relationships are not only experienced by developing societies such as Indonesian society, but also experienced by developed countries such as the United States and others.

Such circumstance is due to the influence of patriarchal ideology of ideology which places power in the hands of men and it exists throughout the world. This situation has begun to get opposition from feminists, because feminists have always been in oppressed situations and circumstances. Therefore, feminists struggle to demand equal status with men in various spheres of life in order to avoid the sub-ordinated circumstances.

In the field of customary law, especially in inheritance law where Hazairin, has been initiated to form a bilateral national inheritance law. Similarly, there was an idea in an adat law seminar in Yogyakarta in 1975 to form a parental national law, but until now the idea has not materialized. Therefore, in Indonesia still apply customary law of inheritance which is diverse in accordance with family system adopted by the people in Indonesia.

In the patrilineal kinship system adopted by the Batak community it is clear that men are placed in a higher position. Men are domiciled as heirs, as surname surnames, as hereditary descendants, as members of indigenous peoples and also have a role in family decision making as well as the wider community. In a society that has a partilinal kinship system women have very low positions, not as heirs, not as descendants of descendants, not as successors of surnames because in marriage honestly (in general) women follow husbands and also not members of indigenous peoples.

It is clear that there has been legal injustice and gender injustice against women because women are always positioned in a weak and subordinated position so that there is discrimination against women. As a solution it is necessary to reposition the position of women in the field of customary law, including in the context of this study is to reposition the position of widow (divorce) in the customary law of Batak. The way is to follow up what was ever initiated by Hazairin, that is by forming the national customary law of bilateral inheritance.

c. Repositioning the Widow's Position through the Establishment of Customary Law of National Inheritance Based on Bilateral System 
The establishment of national inheritance law based on the bilateral system is the effort to create a uniform legal system of inheritance for all people whose legal principles are extracted from the principles of inheritance law of the three prevailing inheritance legal systems, namely customary inheritance law, Islamic inheritance law, And the law of inheritance of the Civil Code $^{26}$ The Islamic inheritance law introduced by Hazairin, was strong enough in the development of Islamic inheritance law in Indonesia which was marked by the birth of the Compilation of Islamic Law (KHI) in 1991. His influence was also felt in the field of development of customary law of inheritance, especially through jurisprudence ${ }^{27}$

The reasons for the establishment of inheritance law with the bilateral system are, among others, due to the tendency of unilateral (patrilineal and matrilineal) family union system changes leading to parental kinship. Such a trend change affects the inheritance of one-way community inheritance into a change towards bilateral inheritance. The reasons for gender equality, democratization and human rights have influenced the change, both in terms of community kinship system and changes in the legal system of inheritance, in addition to educational, religious, and family economics, it can even be said that in the field of legal discovery, The Supreme Court's jurisprudence of the tendency to resolve community inheritance disputes strongly leads to the bilateral system.

If we examine the reality in the field of the three legal systems of inheritance that exist within the community groups, it turns out there has been a deviation in the practice of dividing inheritance, both in the law of inheritance according to the Civil Code, Islam, and custom. That is why Rahmadi Usman concludes that Muslims today seem to be no longer carrying out the Islamic inheritance law as it should. The same deviation also occurs in the law of inheritance according to the Civil Code and custom, because inheritance is not divided equally between the part of the male heirs with the female heir, but rather based on certain considerations of the testator. As a result, there is an heir to get a share of inheritance because with consideration for capital, there is due to education, or there are assisted in paying debt through inheritance. Such modes of distribution are allegedly committed with the consciousness of the testator though not based on the applicable law of inheritance ${ }^{28}$

\footnotetext{
${ }^{26}$ H. S. L. Tobing, "Regulation of Inheritance Law in the National Civil Law System," BPHN Magazine, no. 1, (1989).

${ }^{27}$ Purwoto S Gandasubrata, "Legal Development of Inheritance According to Jurisprudence", in National Legal Law Symposium held by BPHN Jakarta, 10-12 February 1983.

${ }^{28}$ Rahmadi Usman. Development of Civil Law in the Dimensions of History and Political Law in Indonesia. (Jakarta: Pustaka Sinar Harapan, 2003), 9.
} 
The codification of the bilateral inheritance law is in line with the parental familial system commonly adopted by the community. Therefore, in Article 12 Sub-Article F of the Planning Board of LPHN dated 28 May 1962 stated that the national inheritance law system is arranged bilaterally, and the legal system of inheritance like this is in line with the development of parental national law which is parental. Similarly, the decision of the result of National Law Seminar I of 1963 by BPHN that, the law of inheritance for all people is arranged bilaterallyindividual, with the possibility of variation in the bilateral system for the Islamic groups who need it.

In addition, there are also several national seminars which then produce academic manuscripts of legislation inheritance laws and the formulation of national inheritance law principles, among them the result of national seminar in 1987 and the results of the National Legal Law Symposium in Development Era by BPHN on 1- 2 November 1989. In 1995, the Head of the National Legal Development Board formed the formulation team of Academic Paper of Legislation on Inheritance Law, which gave birth to the National Heritage Law Draft (RUU) of $1995^{29}$

The codification system of bilateral inheritance law will have to be differentiated, namely the unity of the law by formulating provisions that are general and applicable to all classes. But on the one hand, there remains a provision that the legal formulation is special and will apply only to certain groups in society. So it resembles the codification of the Number Act. 1 Year 1974 on Marriage. In addition, the codification of inheritance law is differentiated in line with the position and position of the Indonesian nation which consists of various tribes, religions, and beliefs, as well as the prevailing kinship system but within the framework of national insight.

Thus, the codification of inheritance law by differentiation serves as a means of renewal in society. Such codification function is the embodiment of the Roscoe Pound theory, in which law is positioned as "a tool of social engineering". It is also a manifestation of Friedman's Theory of the development of the legal system. Thus it can be concluded that the codification of inheritance law based on bilateral system in the context of repositioning the status of widow in customary law of Batak is very important to be realized.

In the context of this study, at least when viewed from the legal reason of the inheritance of Batak custom is that the customary law of Batak which adheres to paternal fatherhood system, tends toward the parental system by observing the examples that occur, for example in Batak society, there gradually the principle Patrilineal that is almost abandoned to the bilateral family

\footnotetext{
${ }^{29}$ Rumonda Nasution. Husband's Wealth and Inheritance. (Jakarta: BPHN, 1992), 65-75.
} 
life of its nature, which from day to day increase strongly offset the influence of father, especially for Batak people who live in overseas. As a result, in the field of inheritance law there is a change (tendency) towards the bilateral system so that girls get the property because it is judged in terms of responsibility and safety (protection) as a family member that is no different from boys.

Similarly, for a wife whose husband died, it is considered very appropriate if the mother who continues the maintenance of his children until the adult child, because it is considered the mother would be better to take care of the interests of his own son than anyone else. In continuing this maintenance, of course the mother (widow), requires a lot of money. Therefore, it is appropriate that the mother (widow) who takes care of and controls the wealth of the child acquired as the inheritance of his deceased father, during the minors.

From these legal facts, it can be concluded that the customary law of Batak inheritance has evolved towards the bilateral inheritance law system. In addition, it has become a reality that the area of inheritance law prevailing in society is subject to change triggered by various factors. It was argued by Bushar Muhammad that: "For sociological reasons in society, bringing and influencing the state and tendency of Indonesian society towards the bilateral system. The situation is influenced by educational factors; Overseas / migration in a broad sense; Life factor based on household family system; Economic factors; Industrialization, technology, living in big cities; and others".

The triggering factors for the transformation of the kinship system that was based on the clan gradually became more open, and ultimately affected the basic joints of society and the familial system that prevailed toward the parental society. This sociological change is characterized by the assumption that widows are no longer inheritance (levirat) in patrilineal society, besides that there has been a great deal of marriage between national tribes.

Establishment of national inheritance law based on bilateral system relating to legislation step through codification and unification of inheritance law. In reference it is said that the codification and unification of the law, not only to achieve legal certainty, legal uniformity and simplification of law. But also as a legal political guidance for the government in facing the task of fostering national law.

\section{Conclusion}

Based on the above discussion, the author can conclude several things as follows: 
Position of widow in customary law of Batak customary law according to Batak society norm, do not give opportunity to widow to inherit property of her husband. Though the Batak community embraces individual inheritance system, which in this system will be divided inheritance to the heir in accordance with their respective sections, but only boys are entitled to a share of the inheritance. Thus, it is clear that if the widow's position is associated with the inheritance system and the inheritance principle, then it can be said that the widow can not inherit her husband's estate, because the widow is not the heir of her deceased husband.

How to reposition the position of widow in Batak inheritance law in order to have a balanced position with the other heirs a gender perspective, namely by forming the customary law of inheritance national, bilateral. Establishment of inheritance law nationally based system of bilateral is an effort to create a legal system of inheritance that is uniform for all citizens of the principles of the law taken or extracted from the principles of the law of inheritance of the three systems of inheritance law is still valid, the inheritance law customary inheritance law of Islam, And the law of Inheritance of the Civil Code.

\section{References}

Abdurrahman. (1992). Compilation of Islamic Law, Print I. Jakarta: Akademika Presindo.

Ali, Zainuddin. (2008). Implementation of the Law of Inheritance in Indonesia. Jakarta: Sinar Grafika.

Purwanti, Ani. (2017). "Protection and Rehabilitation for Women Victims of Violence according to Indonesian Law (Study on Central Java Government's handling through KPK2BGA)". Diponegoro Law Review, Volume 02, Number 02, 313.

Arikunto, Suharsimi. (2008). Research Procedures A Practice Approach. Jakarta: Rineka Cipta. Busar, Muhammad. (1985). Principles of Customary Law, Cet.3. Jakarta: Pradnya Paramita.

Echols, John M. and Hassan Shadily. (1983). English-Indonesian dictionary. Jakarta: Gramedia. Cet. XII.

Fakih, Mansour. (1996) .Gender Analysis \& Social Transformation. Yogyakarta: Pustaka Pelajar.

Friedman, Lawrence Meir. (2001). American Law: an Introduction, Second Edition, Terj. Wishnu Basuki with title, American Law: An Introduction, Prints I, 2001. Jakarta: PT Tatanusa.

Hadikusuma, Hilman. (2003). Introduction to Indonesian Traditional Law Science. Bandung: Mandar Maju. 
(2003). Customary Law of Inheritance, Cet, 7. Bandung: PT. Citra Aditya

Bakti.

Irianto, Sulistyowati. (2000). Approach to Women's Wise Law, in the Elimination of Discrimination Against Women. Bandung: Alumni.

Lips, Hilary M. Sex and Gender, (1993). An Introduction. London: Myfield Publishing Company.

Musdah, Siti. (2004). Islam Sues Polygamy. Jakarta: Gramedia Pustaka Utama.

Nasution, Rumonda. (1992). Husband's Husband's Wealth and Inheritance. Jakarta: BPHN.

Nazir, Moch. (2008). Research methods. Jakarta: Ghalia Indonesia.

Neufeldt, Victoria (ed.). Webster's New World Dictionary, (1984). New York: Webster's New World Clevenland.

Rasyidi, Lili and Ira Thania Rasyidi. (2004). Fundamentals of Philosophy and The Theory of Law, Prints IX. Bandung: PT Citra Aditya Bakti.

Showalter, Elaine (ed.), Speaking of Gender. (1989). New York \& London: Routledge.

Soejono and H. Abdurahman, (2003). Legal Research Methods. Jakarta: Rineka Cipta. (1997). The Legal System in Indonesia Before World War II, Print XV Jakarta: PT Pradnya Paramita.

Sudiyat, Iman. (2005). Legal Waris Indonesia. Bandung: Refika Aditama.

Sutopo, Heribertus. (2008). Introduction to Qualitative Research. Surakarta: Puslitbang UNS.

Umar, Nasaruddin. (1999). Gender Equality Argument: The Perspective of the Qur'an. Jakarta: Paramadina.

Usman, Rahmadi (2003). Development of Civil Law in the Dimensions of History and Political Law in Indonesia. Jakarta: Pustaka Sinar Harapan.

Vergouwen, C. (2004). Society and Customary Law of Toba Batak. Yogyakarta: PT. LkiS Pelangi Aksara.

Wiranata, I. Gede Ab. (2005). Customary Law in Indonesia. Bandung: PT. Citra Aditya Bakti.

Constitution of the Republic Indonesia.

Book of Civil Code (Burgerlijk Wetboek (BW) Staatsblad Year 1847 Number 23).

Act. Number 1 Year 1974 on Marriage.

Act. Number 7 Year 1984 on the Ratification of the Convention on the Elimination of All Forms of Discrimination Against Women

Act. Number 39 Year 1999 on Human Rights

Presidential Instruction Number. 1 of 1991 on the Compilation of Islamic Law. 
Gandasubrata, Purwoto, S. "Legal Development of Inheritance According to Jurisprudence", in National Legal Law Symposium held by BPHN Jakarta, 10-12 February 1983.

Suteki and Ani Purwanti. The Strategies Of Women Protection In Solving Domestic Violence Cases In Central Java Through Sheltered House. Diponegoro Law Review, October 2016, Volume 01, Number 01, p. 115

Tobing, H. S. L. "Regulation of Inheritance Law in the National Civil Law System", BPHN Magazine, No. 1, Year 1989. 